\title{
Estimation Method of Amount of Tsunami Disaster Wastes during the 2011 off the Pacific Coast of Tohoku Earthquake
}

\author{
Minoru Yamanaka, Naoya Toyota, Shuichi Hasegawa and Atsuko Nonomura \\ Kagawa University, Japan
}

\begin{abstract}
A huge amount of disaster wastes was accumulated along coastline areas of the Tohoku region by tsunami during the 2011 off the Pacific coast of Tohoku Earthquake. It is very important to estimate amount of tsunami disaster wastes as for quick recover and revival of damaged areas. This paper describes a method of wastes amount estimation based on the officially published data analyzed in GIS platform.

As a result of this study, it was found that there is a well relationship between the amount of disaster wastes and submerged area, population, tsunami height and so on, and that the number of damaged buildings within the submerged area using GIS software (Arc Map) has high accuracy in comparison with the published data.
\end{abstract}

Keywords: disaster wastes, tsunami, Tohoku earthquake, estimation

\section{INTRODUCTION}

A huge amount of disaster wastes was accumulated along coastline areas of the Tohoku region by tsunami during the 2011 off the Pacific coast of Tohoku Earthquake. The total amount of tsunami disaster wastes was estimated to be 26.7 million tons. This corresponds to $50 \%$ of the total amount of the waste of Japan in 2009. Tohoku Earthquake caused widespread serious damage. Since the coastal area of Tohoku region shapes a saw-toothed coastline, it is difficult to prepare large places for filling these disaster wastes. And a road for carrying to these treatment facilities is not enough in Tohoku coast line area, most port facilities were damaged seriously. This means the dispose of disaster wastes is in extremely difficult in Tohoku region.

Since a tsunami height in Shikoku region during next Tokai Earthquake or Nankai one will be larger than the Tohoku Earthquake, it can be anticipated that an amount of disaster wastes in Shikoku is also very large. It is very important to estimate an amount of tsunami disaster wastes for quick recover and revival of damaged areas.

This paper describes a method of wastes amount estimation based on the officially announced data analyzed in GIS platform.

\section{CHARACTERISTICS OF DISASTER WASTES \\ 2.1 Characteristics}

A characteristic of earthquake, flood and tsunami disaster wastes are shown in Table 1. These wastes occur suddenly and extensively. However for tsunami disaster wastes, it is necessary to prepare some large places for filling these wastes because amount of wastes were particularly large. And tsunami disaster wastes contain various kinds of debris such as a waste wood, a metal, muddy soil or salt water. In case of disaster wastes mixed with muddy soil, unless the disaster wastes are not removed, these muddy soils are also deal with like disaster wastes. In order to decrease an amount of these soils included in disaster wastes, it is necessary to utilize a technology for separating these soil from wastes. These wastes can be recycled as possible, but soil, wood or metals with sea water can possess harmful effect for an incineration facility.
2.2 Amount of disaster wastes for past some earthquake Table 2 lists an amount of disaster wastes and its situation of damage during past some earthquakes. The amount of disaster wastes of the 1995 Great Hanshin Awaji Earthquake was about 20 million tons ${ }^{[2]}$. About 640 thousand houses were damaged in the earthquake and the amount of wastes corresponded to about eight times as much as the amount of wastes for Hyogo Prefecture in 2006. Fortunately most of them could be disposed at Phoenix landfill disposal site near the damaged areas. The amount of disaster wastes occurred by the 2004 Niigata Chuetsu Earthquake where the epicenter sited on the mountainous area corresponded to about 500 thousand tons. About 120 thousand houses were damaged by the earthquake, $92 \%$ of the disaster wastes were destructed wastes of damaged houses. The rate of concrete debris was $51 \%$, and the one of waste wood was $25 \%$ for the destructed wastes ${ }^{[2]}$.

On the other hand, the amount of flood disaster wastes occurred by Typhoon No.16 in 2004 was estimated 23,123 tons in Takamatsu City, Kagawa Prefecture. Its amount was twice as wastes for one month of this city in 2003. Because the wastes contained salinity, a large amount of unusable household goods was abandoned. Therefore, it was necessary to handle the disaster wastes for a long time ${ }^{[3]}$.

Fig.1 (a)-(b) show a situation of disaster wastes in Rikuzentakata City where big tsunami was attacked during the Tohoku Earthquake. It can be clear that abundant disaster wastes was accumulated.

\subsection{Unit amount of disaster wastes}

A unit amount of disaster wastes can estimate using number of damaged household or extent of damaged area for some past disasters.

Nakamichi (2009) proposed that the unit amount of disaster wastes was $0.571 \mathrm{ton} / \mathrm{km}^{2}$ for wooden house, was $1.47 \mathrm{ton} / \mathrm{km}^{2}$ for $\mathrm{RC}$ buildings, and was $1.27 \mathrm{ton} / \mathrm{km}^{2}$ for steel buildings from 1995 Great Hanshin Awaji Earthquake $^{[4]}$. Shimaoka (2009) estimated that the unit amount of disaster wastes was $0.31 \mathrm{ton} / \mathrm{km}^{2}$ for wooden houses, was 1.09 ton $/ \mathrm{km}^{2}$ for RC buildings, and was 1.80 ton $/ \mathrm{km}^{2}$ for steel constructions ${ }^{[2]}$. Hirayama (2005) estimated that the unit amount of the disaster wastes per a household considering a extent of household's damage for 
some flood disasters was 12.9 tons for completely destruction, was 6.5 tons for a half destruction, was 2.5 tons for partially destruction, was 4.6 tons for inundation above floor level, and was 0.62 ton for inundation under floor level ${ }^{[5]}$. The unit of tsunami disaster wastes for Tohoku earthquake was estimated about 61.9 tons per household or 113 tons per a building ${ }^{[6]}$.

\section{AMOUNT OF TSUNAMI DISASTER WASTES}

Fig.2 (a)-(c) show the amount of disaster wastes in each municipal corporation where damaged by tsunami during Tohoku earthquake.
The amount of disaster wastes is very large for Ishinomaki and Higashi-matsushima, Sendai and so on, which are highly built-up areas in Fig.2 (a).

As for amount of disaster wastes per flooded area in Fig.2 (b), Ishinomaki is more than twice as much as Fukushima. And it can be confirm that the value for Kamaishi and Rikuzentakata where were damaged by more than $10 \mathrm{~m}$ in submerged depth are very large.

And for an amount of disaster wastes per household of flooded area, Yamamoto is expressively large in Fig.2 (c).

Table 1 Characteristics on disaster wastes ${ }^{[1]}$

\begin{tabular}{|c|c|c|c|}
\hline Type & Earthquake disaster & Flood disaster & Tsunami disaster \\
\hline Occurrences & $\begin{array}{l}\text { It occurs heavily and suddenly. } \\
\text { Low earthquake-resisting houses } \\
\text { were damaged mainly. } \\
\text { A crane is necessary for } \\
\text { demolition. }\end{array}$ & $\begin{array}{l}\text { It occurs heavily and suddenly. } \\
\text { Low-level area is damaged } \\
\text { mainly. } \\
\text { Proportion of household refuse } \\
\text { is higher. }\end{array}$ & $\begin{array}{l}\text { It occurs heavily and suddenly. } \\
\text { It is necessary to secure large } \\
\text { places for leaving wastes. }\end{array}$ \\
\hline Characteristics & $\begin{array}{l}\text { Wastes are composed of } \\
\text { household wastes and debris } \\
\text { from fallen houses. } \\
\text { There are many recyclable, } \\
\text { reusable materials. } \\
\text { It can be expected to separate } \\
\text { wastes by demolition } \\
\text { management. }\end{array}$ & $\begin{array}{l}\text { Household wastes by } \\
\text { inundation above or under } \\
\text { floor level. } \\
\text { It is difficult to separate on the } \\
\text { site. } \\
\text { Wastes is perishable because it } \\
\text { contains a water or a soil. }\end{array}$ & $\begin{array}{l}\text { Wastes compose various kinds } \\
\text { of materials such as a wood, } \\
\text { metals or salt water. } \\
\text { Salinity with wastes causes a } \\
\text { harmful effect during } \\
\text { recycling or incineration. }\end{array}$ \\
\hline
\end{tabular}

Table 2 Amount of disaster wastes and situation of damage of previous large earthquakes ${ }^{[2]}$

\begin{tabular}{|c|c|c|c|c|}
\hline Name & $\begin{array}{l}\text { Great Hanshin Awaji } \\
\text { Earthquake }\end{array}$ & $\begin{array}{l}\text { Niigata Chuetsu } \\
\text { Earthquake }\end{array}$ & $\begin{array}{l}\text { Noto Peninsula } \\
\text { Earthquake }\end{array}$ & $\begin{array}{c}\text { Niigata Chuetsu-oki } \\
\text { Earthquake }\end{array}$ \\
\hline Date & January 17, 1995 & October 23, 2004 & March 25, 2007 & July 16, 2007 \\
\hline Magnitude & 7.3 & 6.8 & 6.9 & 6.8 \\
\hline $\begin{array}{l}\text { Main damaged } \\
\text { areas }\end{array}$ & $\begin{array}{l}\text { Kobe, Nishinomiya, } \\
\text { Awaji-shima }\end{array}$ & $\begin{array}{c}\text { Nagaoka, Yamakoshi, } \\
\text { Ojiya }\end{array}$ & Wajima, Nanao, Siga & Kashiwazaki, Kariwa \\
\hline House damage & $\begin{array}{c}\text { Complete collapse } \\
104,906 \text { houses } \\
\text { Half collapse } \\
144,274 \text { houses } \\
\text { Portion damage } \\
390,506 \text { houses }\end{array}$ & $\begin{array}{l}\text { Completely collapse } \\
3,157 \text { houses } \\
\text { Half collapse } \\
13,808 \text { houses } \\
\text { Portion damage } \\
103,854 \text { houses }\end{array}$ & $\begin{array}{l}\text { Completely collapse } \\
638 \text { houses } \\
\text { Half collapse } \\
1,563 \text { houses } \\
\text { Portion damage } \\
13,553 \text { houses }\end{array}$ & $\begin{array}{l}\text { Completely collapse } \\
1,224 \text { houses } \\
\text { Half collapse } \\
5,241 \text { houses } \\
\text { Portion damage } \\
34,277 \text { houses }\end{array}$ \\
\hline $\begin{array}{l}\text { Amount of } \\
\text { disaster wastes }\end{array}$ & 20 million tons & 0.49 million tons & 0.43 million tons & 0.36 million tons \\
\hline $\begin{array}{l}\text { Regions: } \\
\text { wastes in } 2006\end{array}$ & $\begin{array}{l}\text { Hyogo Pref.: } \\
0.25 \text { million tons }\end{array}$ & $\begin{array}{l}\text { Niigata Pref:: } \\
1.12 \text { million tons }\end{array}$ & $\begin{array}{l}\text { Ishikawa Pref.: } \\
0.5 \text { million tons }\end{array}$ & $\begin{array}{l}\text { Niigata Pref:: } \\
1.12 \text { million tons }\end{array}$ \\
\hline
\end{tabular}




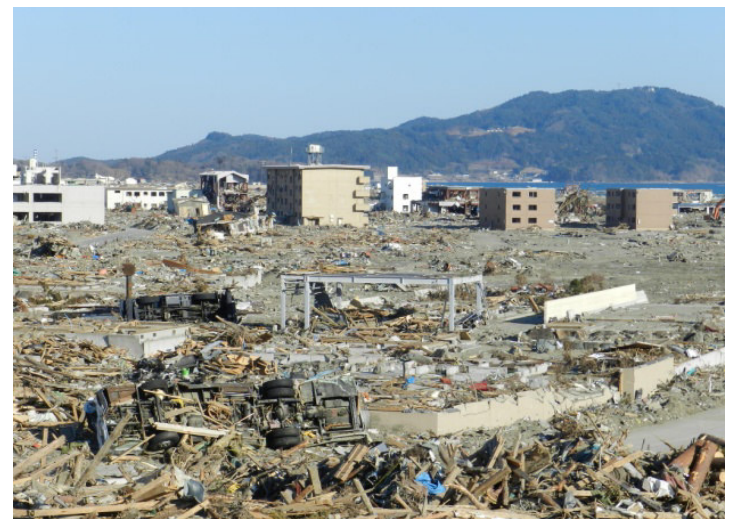

(a) photo on April 6, 2012.

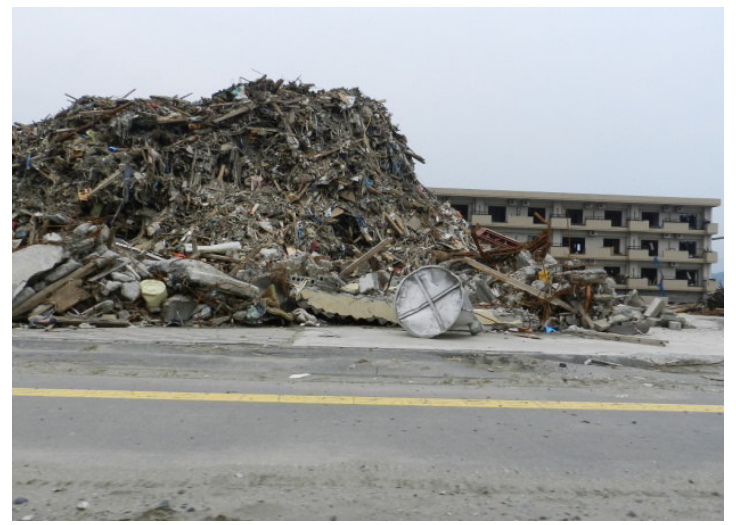

(b) photo on June 5, 2012.

Fig.1 Situation of disaster wastes in Rikuzentakata City, Iwate Prefecture.

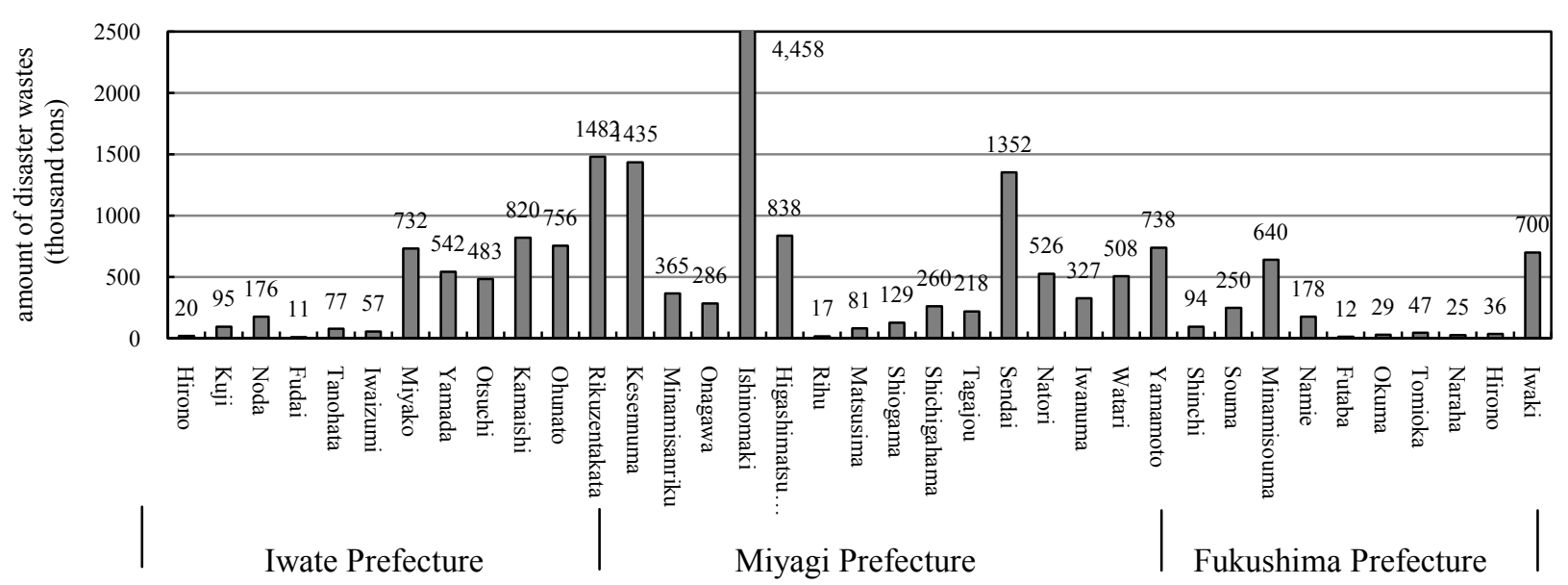

(a) Amount of disaster wastes

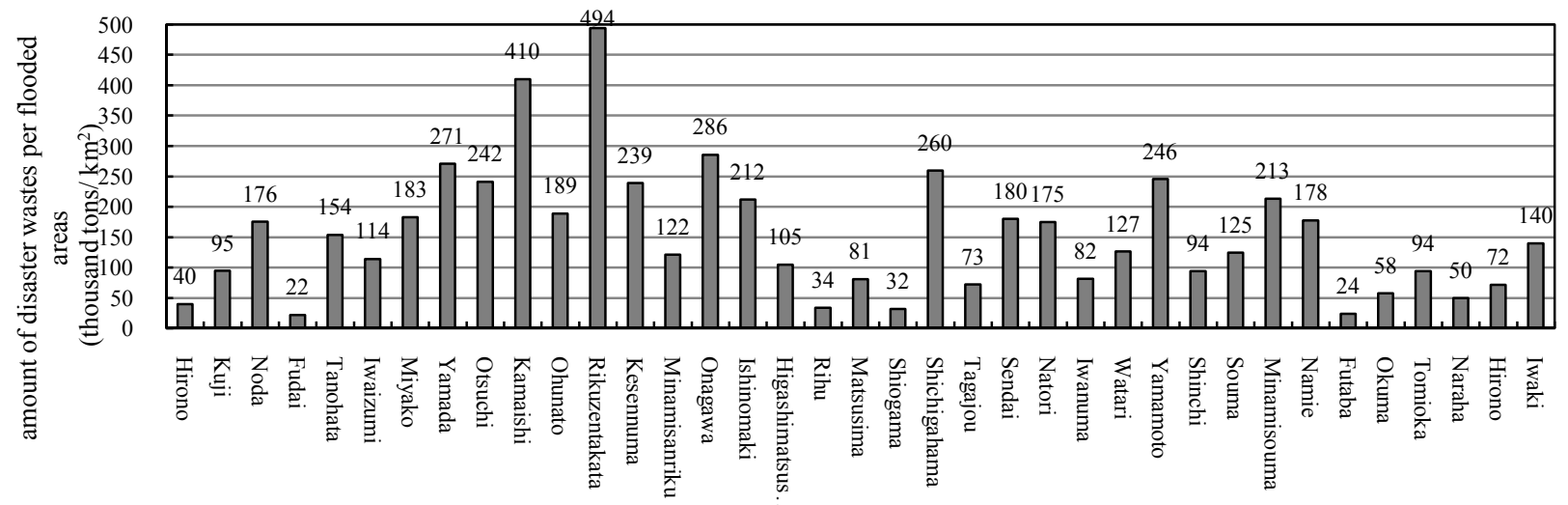

(b) Amount of disaster wastes per submerged area
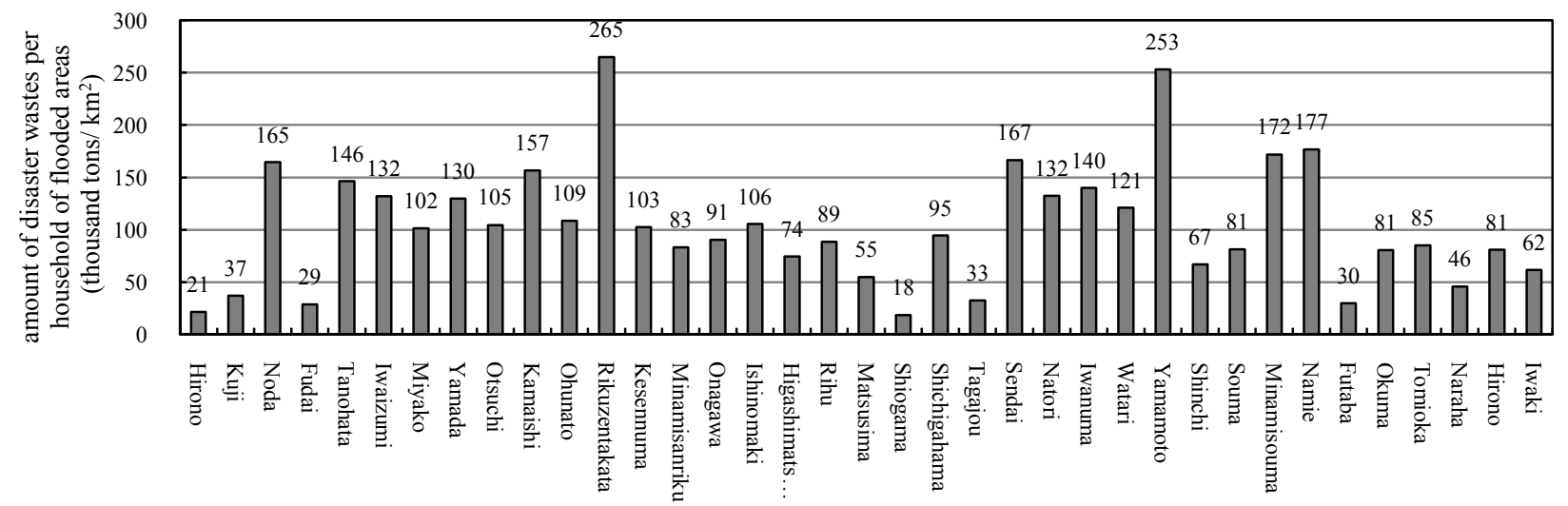

(c) Amount of disaster wastes per household of submerged area

Fig.2 Difference of amount of disaster wastes for damaged municipal in Tohoku region 


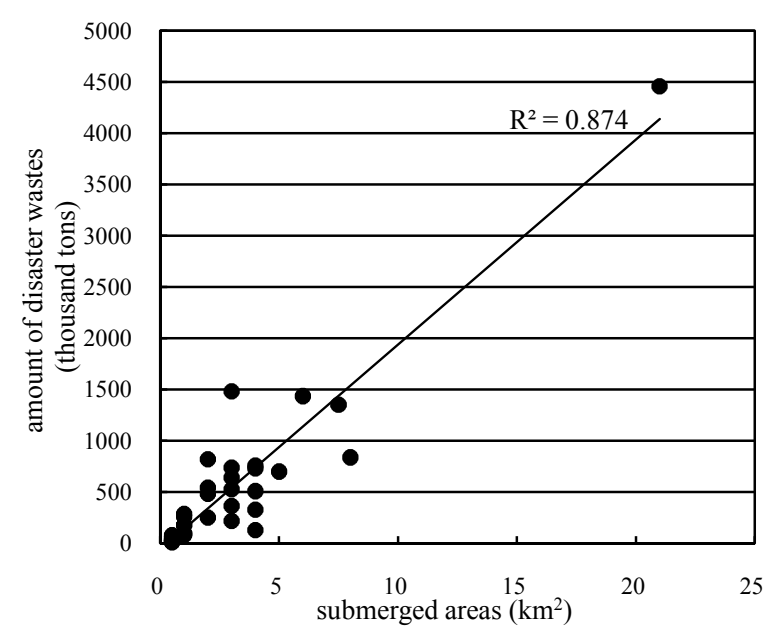

(a) Submerged area

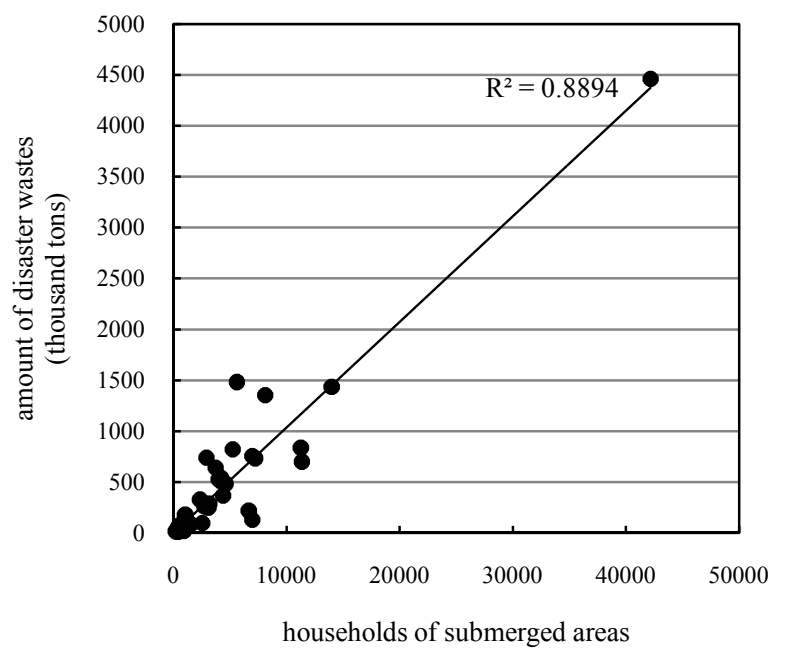

(b) Number of households

Fig.3 Relationship with amount of disaster wastes

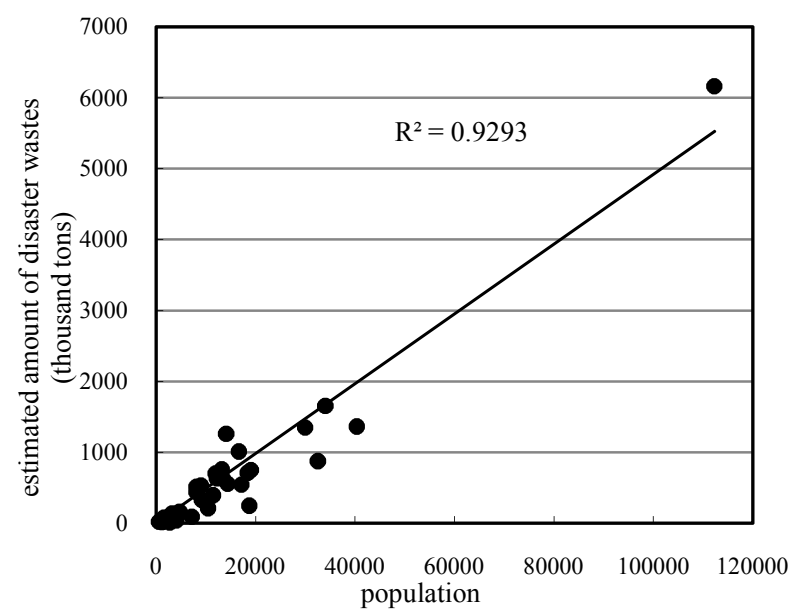

Fig.4 Relationship between number of population and amount of tsunami disaster wastes

Fig.3 (a) ,(b) show relationships with amount of disaster wastes. The relationship between a submerged area by the tsunami and amount of the disaster wastes has a positive correlation in Fig.3 (a). And because it seems that the correlation is separated by scale of the submerged area, it must be consider separating the submerged area into an urban area and an agricultural one. On the other hand, it clear that the correlation between number of households within the submerged area and amount of tsunami disaster wastes was very high as shown in Fig.3 (b).

Fig. 4 shows a relationship between number of population and amount of tsunami disaster wastes. It can be clear that the correlation is very high. Therefore, unit amount of disaster wastes as per household is estimated at 104 tons. It is necessary to discuss this value in detail, for instance as for damage level such as such as complete collapse, half collapse and a portion damage of household.

\section{RELATIONSHIPS WITH HEIGHT OF TSUNAMI}

The amount of disaster wastes occurred at submerged areas changes according to a height of tsunami.

Fig.5. shows a relationship between a typical height of tsunami and an amount of disaster wastes per submerged flooded areas for municipal corporations along the coastal

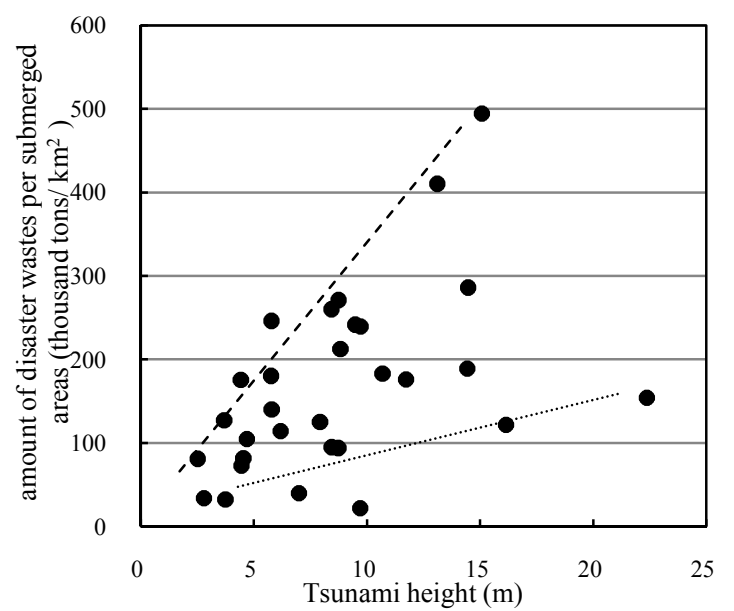

Fig.5 Relationship between height of tsunami and amount of disaster wastes per submerged areas

area at Tohoku region. Now, a height of tsunami means a height from T.P. (Tokyo Bay mean sea level). It can be seem that there are two lines on the relationship. This means that there is the difference in proportion of residential area and firm land and so on within submerged area.

\section{INFLUENCE OF SUBMERGED DEPTH}

Fig. 6 shows a change of the damaged number of wooden buildings in each submerged depth. The depth of tsunami means a height from its ground level (G.L.). The number of the damaged building means the total number of wooden buildings from 31 cities along the coast area of Tohoku. It is clear that the number of damaged buildings peaks when the depth is under $0.5-1.0 \mathrm{~m}$, and that it decreases according to the depth of tsunami. A ratio of number of half collapse and of portion damage are larger until the depth is under $2.0 \mathrm{~m}$, and a ratio of complete collapse increases over the depth is $2.0 \mathrm{~m}$. And it is found that a ratio of the division of damaged building changes according to a submerged depth of tsunami regularly. Therefore it can be said that a damage degree of buildings has highly relationship with the depth of tsunami. 


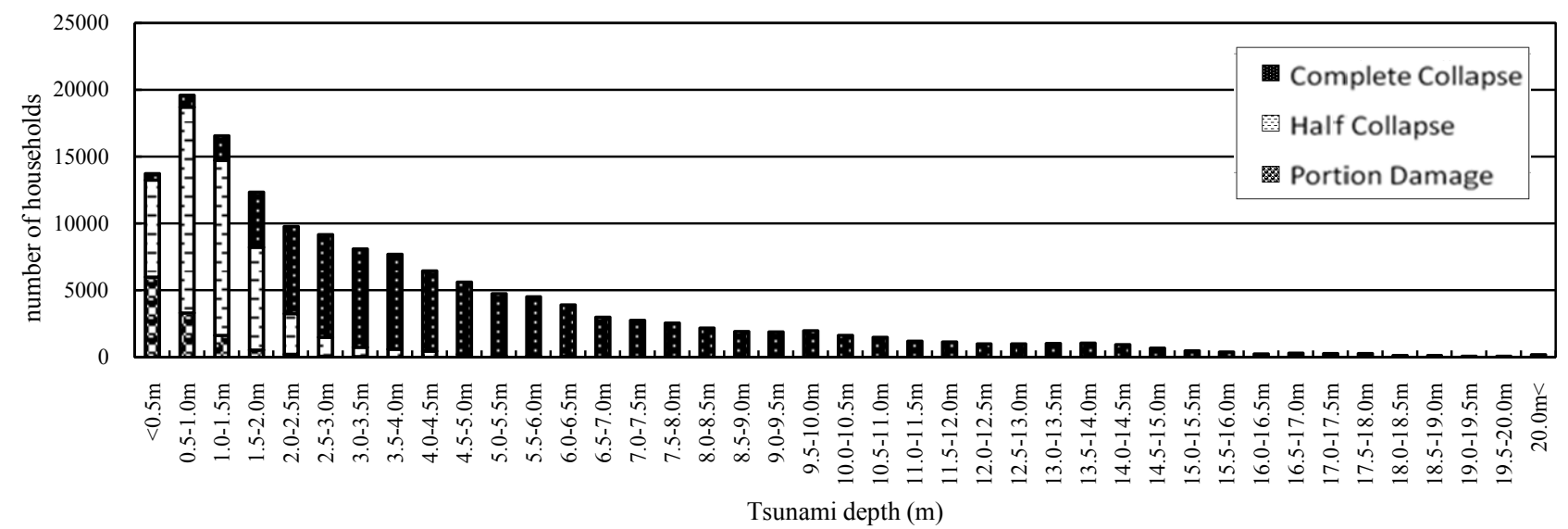

Fig.6 Variation number of wooden houses with Tsunami depth ${ }^{[7]}$

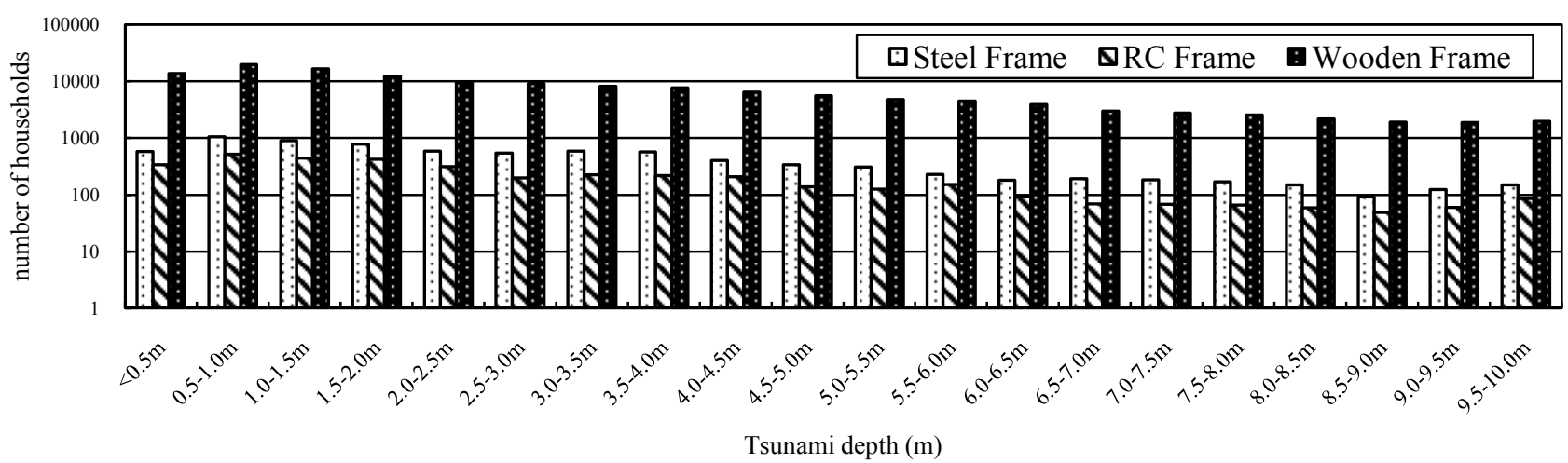

Fig.7 Variation number of damaged households separated each structure with Tsunami depth ${ }^{[7]}$

Fig. 7 shows a change of the number of damaged buildings under the $10 \mathrm{~m}$ depth within the building damage is remarkable. It is found that the number of wooden frame household is the largest among the other frame ones. And the number of damaged steel frame households and RC frame ones is about $10 \%$ of wooden frame regardless of depth of tsunami respectively. From this, the difference of number of damaged buildings is very large, but it is found that the depth and the ratios of number are small comparatively.

Therefore the amount of disaster wastes has a relationship among the submerged area, the number of the building collapse and the population. And, it seems that the ratio of the number of damaged buildings in each frame structure is almost constant regardless to the depth. it can be said that the unit amount of wastes according to depth of tsunami was revealed by dividing the building damage revel.

\section{ESTIMATION METHODS USING GIS}

\subsection{Number of buildings within submerged area}

A tsunami damages every structure catastrophically for instance of buildings, lifelines and so on in general. And a damage of tsunami is well known to spread along widely coastal areas. In the past study, the roughly method ${ }^{[8]}$ estimating the number of the damage houses per 1 mesh was proposed by Kotani et al (1998).

In this study, we attempted to estimate the number of damaged buildings within the submerged area using GIS software (Arc Map) and some public data on Tohoku Earthquake. The building data used in this study was used

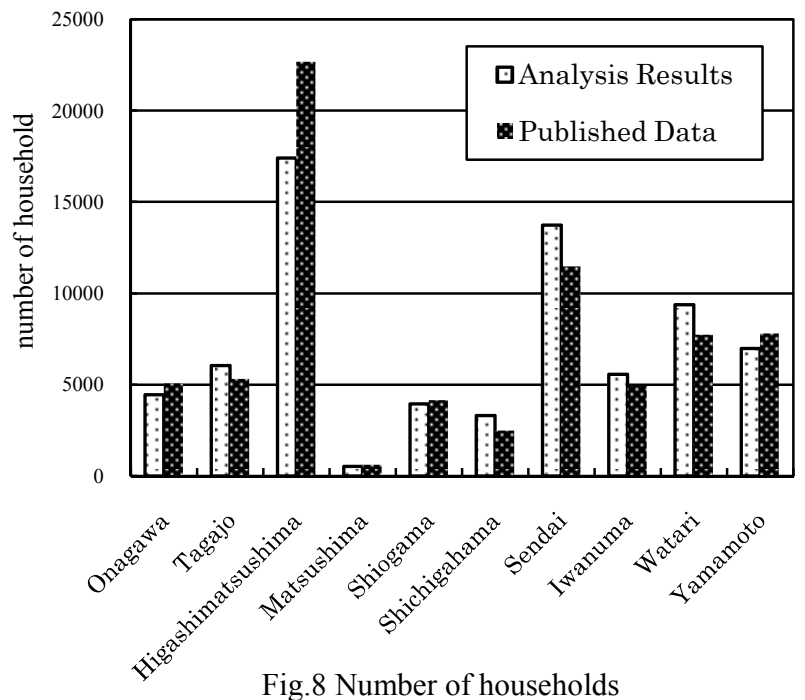

the 1:2500 scale topographic maps with circumference line data of buildings by Geospatial Information Authority of Japan. A submerged area by the tsunami was extracted from the tsunami submerged area map ${ }^{[9],[10]}$.

\subsection{Calculation of number of damaged buildings}

The number of damaged buildings within the submerged area was calculated overlaying the number of buildings as a polygon. The research area in this study is total of 10 municipals along the coast in Miyagi Prefecture.

Fig. 8 shows the number of damaged buildings estimated by GIS and one by published data ${ }^{[1]}$ at the submerged area. It can be said that there is large difference comparatively 
between an estimated number and the published number for serious damage area such as Higashi-Matsushima City and Sendai City. But it clear that this proposed method can estimate justly for other area. As for this reason, it is considered that number of buildings within these urban cities could not calculated accuracy because the data of the farm village area was not included in the used data.

\section{CONCLUSION}

In this study, we estimated of the amount of tsunami disaster wastes during the 2011 off the Pacific Coast of Tohoku earthquake. As a result of this study, the followings could be clear;

1) There is a correlation between the unit amount of the tsunami disaster wastes among the submerged area, the households or populations for the damaged municipal corporations along the coastal area at Tohoku region.

2) There are two lines on the relationship. This means that there is the difference in proportion of residential area and firm land and so on within submerged area.

3) The number of damaged buildings made of steel frame and of RC frame is constant to about $10 \%$ of wooden buildings regardless of submerged depth of the tsunami.

4) The number of damaged buildings peaks when the depth is under $0.5-1.0 \mathrm{~m}$, and that it decreases according to the depth of tsunami. A ratio of number of half collapse and of portion damage are larger until the depth is under 2.0 $\mathrm{m}$, and a ratio of complete collapse increases over the depth is $2.0 \mathrm{~m}$.

5) There is large difference comparatively between an estimated number and the published number for serious damage area such as Higashi-Matsushima City. But it clear that this proposed method can estimate justly for other city.

\section{REFERENCE}

[1]YAMANAKA Minoru, HACHIMURA Tomoaki, "The Problems about Disposal of Disaster Waste", Geotechnology and Survey, Japan Geotechnical Consultants Association, Ser. No.130, pp.34-39, 2011 (in Japanese)

[2]SHIMAOKA Takayuki, "Abnormal Weather and Disaster Waste accompanied by Global Warming", Disaster Waste, Japan Society of Material Cycles and Waste Management, Vol.3, Chuohoki, pp.3-20, 2009 (in Japanese)

[3]Waste Management and Recycling Department, Measure Guideline of flood waste, Ministry of the Environment, 2005.9.1.
[4]NAKAMICHI Tamehiro, "Waste Disposal Act of Great Hanshin Awaji Earthquake", Disaster Waste, Japan Society of Material Cycles and Waste Management, Vol.3, Chuou-houki, pp.23-46, 2009 (in Japanese)

[5]HIRAYAMA Nagahisa, "Estimation Procedure for Quantity of Disaster Waste from the Viewpoint of Emergency Responses of Public Authorities at Flood Disaster", Journal of Environment System, Japan Society of Civil Engineers, Vol.33, pp.29-36, 2005 (in Japanese with English abstract)

[6]National Institute for Environmental Studies, "Unit amount of disaster waste", Disaster Response Network, 2011.6.28.

[7]MLIT, "For Compilation of Research to Reconstruct Damaged City from the Great East Japan Earthquake", http://www.mlit.go.jp/toshi/toshi-hukkou-arkaibu.html

[8] KOTANI Misa, IMAMURA Fumihiko, SHUTO Nobuo, "Run-up Simulation and Damage Estimating Method by Tsunami using GIS Data", Journal of Coastal Engineering, Japan Society of Civil Engineers, Vol.45, pp.356-360, 1998 (in Japanese)

[9]HARAGUCHI Tsuyoshi, IWAMATSU Akira, "Detailed Maps of the Impacts on the 2011 Japan Tsunami”, Vol.1: Aomori, Iwate and Miyagi Prefectures, Japan: Kokon-Shoin, 2011.

[10]HARAGUCHI Tsuyoshi, IWAMATSU Akira, "Detailed Maps of the Impacts on the 2011 Japan Tsunami”, Vol.2: Fukushima, Ibaraki and Chiba Prefectures, Japan: Kokon-Shoin, 2011.

[11]Statistics Bureau, "Statistical Data for the Great East Japan Earthquake", Ministry of Internal Affairs and Communications, 2011.11.

Int. J. of GEOMATE, March, 2013, Vol. 4, No.1 (Sl. No. 7), pp.456-461

MS No. 2141 received June 26, 2012, and reviewed under GEOMATE publication policies.

Copyright (C) 2013, International Journal of GEOMATE. All rights reserved, including the making of copies unless permission is obtained from the copyright proprietors. Pertinent discussion including authors' closure, if any, will be published in the March, 2014 if the discussion is received by Sept, 2013.

Corresponding Author: Minoru Yamanaka 